\title{
TURNING A SCHOOL ATLAS INTO A HISTORY ATLAS: THE BOS-ATLAS ONLINE 1877-1939
}

\author{
Ferjan Ormeling ${ }^{\mathrm{a}}$ \\ ${ }^{a}$ Utrecht University; F.J.Ormeling@uu.nl
}

\section{Introduction}

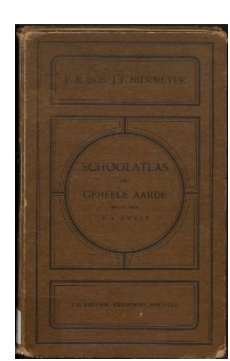

This is a photograph of the editor's copy of the 31 st edition of the Bosatlas, the main school atlas in the Netherlands. It was used to prepare for the next edition, to be published in 1929, and for that purpose all the maps in the atlas are heavily annotated, showing all the changes to be made to the lithographic printing stones the atlas was printed from. If we zoom in on one of the map pages, like the one with the administrative map of Africa, (see figure 2) we can see the kind of changes to be made: changes in the state boundaries (especially for Libya), in the names (like Cyrenaica instead of Barka), in the letter type (as names in capital letters were reserved for state names, Nubia had to be written in lower case), in the location of towns or railway lines. Moreover, there were new towns to be shown, like Amman, capital of Transjordan. Even the sources to be used for the corrections are indicated, like the remark referring to Iraq, that its rivers and planned railway lines had to be redrawn following p. 65 of the Stieler atlas. The result can be seen in the next edition, the $32 \mathrm{nd}$, and you can see that all the changes indicated have been implemented.

This possibility, of having two successive editions of the atlas side by side, for them to be compared, is the main tool of the new atlas service built by Utrecht University library (to be found at http://objects.library.uu.nl/reader/viewer_sync.php?obj=1 874-330964\&pagenum $=7 \&$ lan=nl\&src $=$ reader. The atlas concerned, the Bosatlas, so called after its first editor Pieter Bos, is something of an institution in the Netherlands, as it has been the main school atlas in the Netherlands for most of its 140 years of existence. The 55 th edition of the atlas was published in 2016. It is used in geography classes all over the country, by pupils whose parents and grandparents have used it likewise in school. Comparison of the maps in the previous editions with the present one, would inform them about the changes that have taken place in the world since 1877 , and this gave us the idea to turn this school atlas everyone in our country is familiar with into a history atlas.

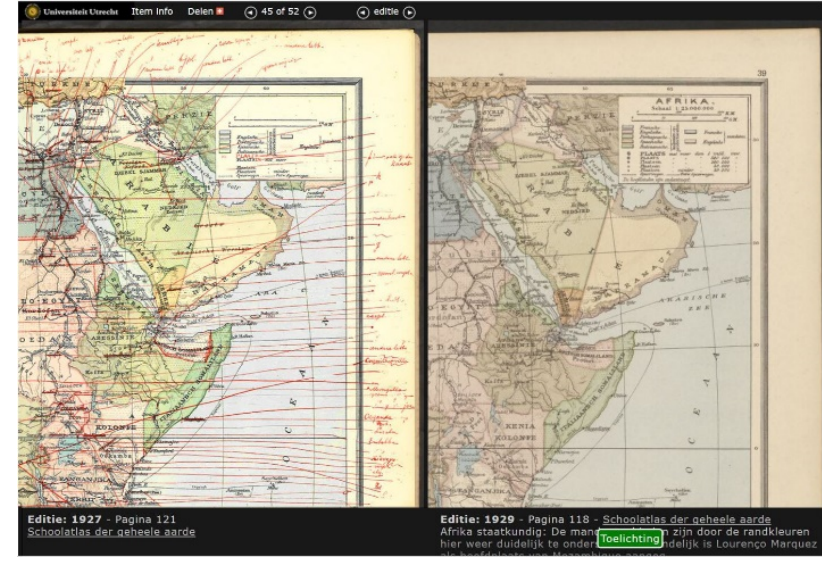

Fig. 2. Comparison of the 31 st and 32 nd edition

\section{Functionality}

So, we built a tool that allows for the comparison of all maps in the same edition and also of the same map (like for example the administrative map of Africa) in successive editions. By zooming in one can get a good idea of the changes in the successive editions. To ease comparisons, when one zooms in on the one map, the other map is automatically zoomed in on as well, producing the same cutout. When one presses the clarification button ('Toelichting'), the changes on the map are explained in map commentaries. Over the years, the number of spreads or double atlas pages increased from 24 to 43, but, basically, the same overview maps would be re-iterated edition after edition, although of course after being updated. It is the number of thematic or topical maps that increased, but these additions were all rather short-lived.

The map commentaries not only indicate what changes occurred in an area between successive editions, they also try to explain why these changes occurred. So they would provide both clarification and explanation. And these explanations would range from a description of natural phenomena, like the changes in coastline of Lake Chad or Lake Helmand, to the reasons or ideas behind man-made changes on the ground, like new railways, dams, canals, towns, or conceptual changes like changes in boundaries or place names.

The maps can be downloaded, and apart from the zoomoption the occasional texts in the atlas (like the editorial foreword or the list of contents) can be characterrecognised (OCR), and there is a complete bibliographical documentation of the atlas items. In order to investigate the atlas structure, more atlas pages can be shown simultaneously, providing a synchronic overview 
as opposed to the diachronic overview that can be produced by arranging and combining the same cut-out from consecutive atlas editions (Figure 3 ).

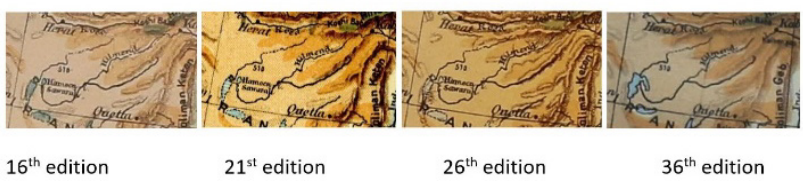

Fig. 3: changes in the banks of the Helmand lake between Iran and Afghanistan in various editions of the Bos-atlas.

\section{Possibilities for use}

Comparison of the maps would allow the high school pupils to which the website is directed to find out about the way the Dutch in general and the atlas editors in particular viewed the world in the past, as well as the changes in those views and attitudes as reflected in the maps and in the structure of the atlas. It would allow them to see the changes in our knowledge of the world, as the results of exploration, both marine and terrestrial, and it would allow them to grasp the changes in the world itself since the 1870ies, in boundaries, in infrastructure, due to urbanization, to armed conflicts or international cooperation, as well as the changes due to the construction of railways, highways, reservoirs, canals and ports.

With the help of this atlas tool, high school pupils could be asked to find out about for instance:

- the history of exploration of a region since 1877 - in Central Africa, New Guinea or the polar regions or, different altogether, the changes in the bathymetrical representation of the Pacific.

- the natural changes in our world, even before the effects of global warming took place, like the annual changes in lakes and rivers

- the man-made changes we made to our environments, especially on the larger-scale maps of the home country. The spectacular growth of the port of Rotterdam, which in the 20th century had the largest turnover in the world, was for instance also documented in the portrayal of the growth of its port basins in the atlas. And of course such changes (infrastructure, population, boundaries, administration) could also be described for particular countries as a whole, as portrayed in the Bosatlas.

Examples of more advanced tasks would be:

- describe what happened in a specific time period all over the world (for instance, which political changes occurred immediately prior to the Second World War? Or: when did airfields start to be built?)

- describe the changes in the regional relationships between countries, as visible from boundary changes, for example between Brazil, Bolivia and Paraguay (due to the Chaco Wars), or between Chile, Bolivia and Peru (due to the War of the Pacific). Or:
- analyse the existence of regional differences in the advent or emergence of specific phenomena. Examples are the construction of railways in specific continents or globally, the construction of reservoirs, or the emergence of cities with over a million inhabitants.

- or, an even more difficult task still, but most worthwhile, because it teaches pupils to think about bias: try to find changes in attitude, either by the editors, by educational authorities or by society at large. In the 1930ies the atlas portrayed colonies as the brightly coloured norm (see Figure 4), the world consisted of colonial powers and colonies, while states without colonies ('Staten zonder koloniën en bezittingen') had a nondescript blueish shading. In the colonies, like in Indonesia, in the town plans a distinction was made between the stone and brick buildings inhabited mostly by Europeans and the wooden houses inhabited mostly by the native population. It was only after Indonesia's independence that this distinction was dropped. It originated in the 19th century European practice of showing wooden buildings on topographic maps in red and brick or stone ones in black, as this was an important indicator for the artillery, but when applied to the colonies it came to denote the difference between the more well-to-do colonizers that could afford brick buildings and the native population.

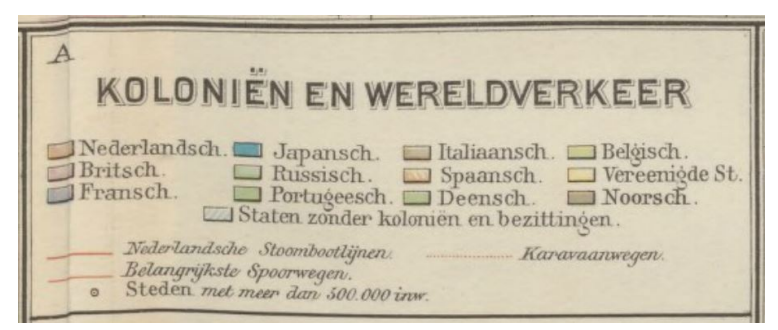

Fig. 4 Legend of the map on colonies and world transportation from the 32 nd edition (1931).

For executing those tasks, pupils would have to reconstruct the editorial process: why were those changes made to the maps, what events caused the maps to be changed, why did the editors think them relevant enough for incorporation on the map, what was the current attitude towards it, etc.

As indicated, to help the pupils, texts have been prepared to highlight the changes from each edition to the next, pinpointing the changes in the features represented or selected. Apart from a general introduction to the atlas and its structure, to the symbols used and to the representation of place names, a $250 \mathrm{p}$ manual has been produced, that can be downloaded, to help with the interpretation. It is geared especially to a discussion of the legends and helps to explain them if necessary. All in all, the atlas tool helps high school pupils to get a better understanding of the World's recent history 1877-1939, 
that is from the Berlin Congress up to the Second World War.

\section{Warnings to the users}

But for the users to get this better understanding, some warnings must be heeded by them. We have already mentioned the distorted world view of colonialism, and added to that there are the bias of the various atlas editors over time and the changing views of society, also expressed in the changing school geography curriculum. The successive atlas editors saw geography consecutively, as determinism, as human geography, as economic geography or as cultural geography, and this was expressed in their choice of themes for the thematic maps in the atlas. During this whole period society evolved and became more interested in human relationships and in ecology. And there was a certain traditionalism as well for example regarding traffic and transportation: In the $1870 \mathrm{~s}$ in the Netherlands bulk goods would still be transported by river barges, and if for passenger transportation trains and tramways had become pre-eminent, the heyday of rail network transportation was already over in the 1930s. Still, it took until the 1960s before the road network was represented on the maps in the Bosatlas as well.

Apart from these changes in attitudes, there were distinct differences in the pace with which specific categories of map information were updated. To explain this, we first have to turn to the types of maps contained in the atlas: there were:

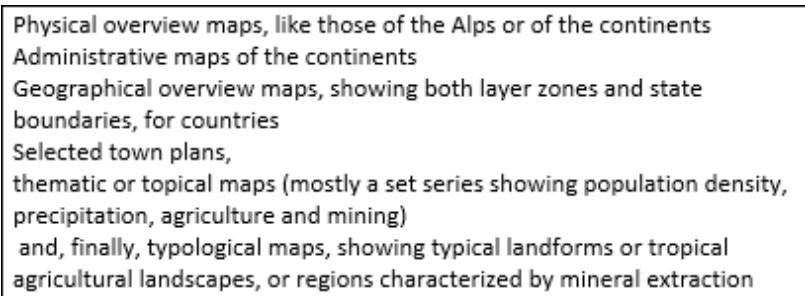

Box 1. Different types of maps in the Bosatlas

Of these, only the first three categories were regularly updated, the others were rather replaced than updated, with the exception of the plans of Amsterdam and Rotterdam. That is why in the atlas comparison tool we mainly looked at the first three categories.

The contents of these three remaining classes was also differentially updated. On country or continental maps, boundaries were always immediately updated, as was the case with railway lines and shipping lines linking the Netherlands to overseas destinations, as we were still an important shipping country at the time, with the world's fourth fleet. The updating of population numbers of cities or new bathymetric information on those maps took much longer to be implemented in the atlas. While for the first categories (boundaries and communication lines) the atlas editor looked after the documentation himself, for the other ones he depended on copying reference atlases like the Stieler atlas or the Times.

For the Dutch colonies, the atlas presented the state of the art: atlas editors even apologized in the atlas foreword when, due to lack of time, the latest administrative change in the ever-changing administrative subdivision of the Netherlands East Indies, or the latest change in official place names had not been implemented.

For the metropolis itself, the drainage situation of our delta demanded changes in dikes, canals and weirs to be rendered immediately on the maps, and the same applied to changes in population thresholds for settlements, and the operation of railway and tramway lines. Apparently, the editors would be taken to account in the local press when these changes would not be reflected on the map in the next edition of the atlas.

One of the most spectacular sequences are those of the map of the port of Rotterdam where almost every new edition showed new extensions of the port area. But these maps also show artefacts that since have lost their function, like the quarantine station, that up to the second world war was a fenced-in area along the river, that since the advent of penicillin was no longer necessary and was closed as a medical facility. Since then a colony of artists has moved in as squatters. So, the maps of the past editions of the Bosatlas are also a silent witness of the past, that we can give back its voice with this new atlas comparison tool.

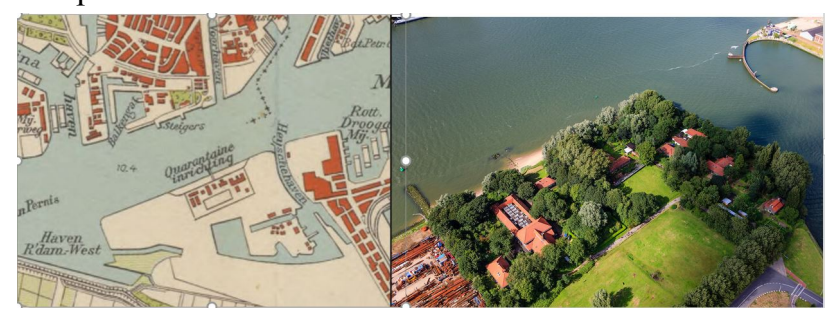

Fig.5. The 'quarantine-island' in the port of Rotterdam in 1934 and 2017.

\section{References}

Ormeling, F.J. en R. van der Vaart (2005) Biografie van de Bosatlas. Groningen: Wolters-Noordhoff

Ormeling, Ferjan (2006) De weergave van Suriname in de Bosatlas 1877-1940. Caert-Thresoor vol. 25-2, 2006, pp 25-32

Ormeling, Ferjan (2006) The origins of the Bosatlas and its portrayal of Hungary. P 315-322 in Zentai László, Györffy János and Török Zsolt, (eds.), Térkép Tudomány: Tanulmányok Klinghammer István professzor 65. születésnapja tiszteletére (= Map Science: Papers in Honour of the 65th Birthday of Prof. István Klinghammer). Studia Cartologica 13. Budapest: ELTE Térképtudományi és Geoinformatikai Tanszék.

Ormeling, Ferjan (2015) The rendering of Greece in Dutch school atlases. Pp 362-375 in: Arvanitis, A. et al. (eds.) Cartographies of mind, soul and knowledge. Special issue for Professor Emeritus Myron Myridis. School of Rural and Surveying Engineers. Thessaloniki: AUTH.

Ormeling, Ferjan (2016) A Total History Atlas: the Bosatlas editions online 1877-1939. pp 285-303, in 2016 Conference on the making of historical atlas. Seoul: Northeast Asian History Foundation. 
Ormeling, Ferjan (2016) The rendering of Iran in a European School atlas. In: Sahab 80 Years Cartography. Forthcoming.

Ormeling, Ferjan (2017) Colonialism in the Bosatlas. In: M. Altic and I. Demhardt (eds.) History of Cartography series, Springer Verlag, forthcoming. 